\title{
Fundações Estatais de Direito Privado: ViabiLIDAde JURídica do PLP N. 92/2007
}

Juliana Bonacorsi de Palma ${ }^{(*)}$

\section{RESUMO}

O presente artigo tem por objeto a análise da viabilidade jurídica do Projeto de Lei Complementar n. 92/2007, que se destina a disciplinar as fundações estatais de direito privado. Para tanto, foram identificados os obstáculos jurídicos atinentes ao tema das fundações governamentais a partir do relato do processo legislativo do PLP n. 92/2007, quais sejam, imprecisão semântica do termo "fundação pública", indeterminação do regime jurídico de direito privado e dúvidas quanto à possibilidade de as fundações estatais conferirem eficiência à Administração Pública. Em seguida, cada aspecto foi analisado por meio de estudo doutrinário e normativo. Como resultado da pesquisa, constatou-se que o modelo de fundação estatal proposto pelo referido projeto ainda não é juridicamente viável na medida em que não conseguiu vencer a celeuma terminológica que, consequentemente, impede a identificação mais precisa do regime de direito privado. Quanto à eficiência, concluiu-se que a mera previsão do regime de direito privado não é suficiente para dotar a Administração Pública de flexibilidade de gestão e eficiência, fazendo-se necessária a adoção de instrumentos contratuais.

\section{Palavras-chave}

Fundações Estatais de Direito Privado; Gestão Contratual; Organizações Sociais; Prestação de Serviços de Saúde.

(*) Mestranda em Direito Administrativo pela Universidade de São Paulo e pesquisadora da Fundação Getúlio Vargas — Direito GV GV Law. E-mail: <juliana_bpalma@yahoo.com.br>. Recebido em 05.12.08. Aprovado em 31.01.09. 


\begin{abstract}
This article intends to analyze the juridical viability of the Project of Complementary Law PLP N. 92/2007 that will regulate the private law state foundations. It was pointed the main obstacles relationated with the theme of state foundations were pointed PLP N. 92/200: the semantically indetermination of the expression "state foundation"; indetermination of the private law discipline and doubts about the possibility of the private law state foundations to give the required efficiency to Public Administration. After that, each point was analyzed by normative and doctrinaire studies. As result of this research, this article pointed that the proposed model of state foundation is not juridical viable, once the terminological issue has not already been transposed and, consequently, remains an imprecisely identification of the private law discipline. In relation to efficiency, the merely announce of the private law discipline in the text of law is not sufficient to provide a flexible and efficient management; contractual instruments are necessary to reach this aim.
\end{abstract}

\title{
Keywords
}

Contract Management; Health Services; Private Law State Foundations; Social Organizations.

\section{INTRODUÇÃO}

\section{TRAMITAÇÃO DO PLP N. 92/2007 E DIFICULDADES DE ANÁLISE DAS FUNDAÇÕ̃ES GOVERNAMENTAIS DE DIREITO PRIVADO}

Apresentado no dia 13 de julho de 2007 à Câmara dos Deputados pelo Ministério do Planejamento, Orçamento e Gestão, o Projeto de Lei Complementar n. 92/2007 (PLP n. 92/2007) destina-se a regulamentar o inciso XIX do art. 37 da Constituição Federal por meio da definição das áreas de atuação das fundações estatais de direito privado(1). O projeto foi distribuído às Comissões de Trabalho, de Administração e Serviço Público e de Constituição e Justiça e de Cidadania para tramitação legislativa, que tem se mostrado um tanto quanto "agitada" em razão de calorosos debates sobre (i) a definição das áreas abrangidas pelo teor da proposta; e (ii) o reconhecimento da finalidade do Projeto ${ }^{(2)}$.

(1) As expressões fundação governamental e fundação estatal serão empregadas neste artigo como sinônimas e designarão todas as fundações integrantes da Administração Indireta do Estado, qualquer que seja seu regime jurídico. São suas espécies as fundações de direito público (fundações autárquicas) e as fundações estatais (as fundações governamentais de direito privado). Embora o tema seja oportunamente retomado com maior profundidade no item 3 do trabalho, faz-se desde logo esse esclarecimento para auxílio da leitura do texto.

(2) Os diversos requerimentos dirigidos à Mesa da Câmara dos Deputados para criação de uma Comissão Especial para debater o PLP n. 92/2007 e para realização de audiência pública sobre o teor do Projeto corroboram para evidenciar as dificuldades de aprovação da lei das fundações de direito privado. 
Quanto ao primeiro aspecto - abrangência da fundação estatal de direito privado —, evidenciou-se significativa ampliação do PLP n. 92/2007; se originariamente o Projeto versava somente sobre a área de saúde, nada menos que oito outras áreas foram acrescentadas em seu art. 1‥ Ainda assim, remanesce dúvida sobre a taxatividade das áreas contempladas no texto legal: poderia a Administração Pública criar fundações governamentais de direito privado para desempenhar atividades não exclusivas do Estado que não constem em algum dos incisos do art. 1ํ?

Em relação à finalidade do PLP n. 92/2007, falta um discurso coeso sobre o escopo do Projeto no Legislativo. A que se destina esta proposta? Quais são os problemas que ele se propõe a superar? Essas são perguntas de fundo dos debates parlamentares sobre o tema das fundações estatais de direito privado que recebem uma pluralidade de respostas.

Primeiramente, o PLP n. 92/2007 se destinaria a impedir a criação de fundações sob o regime de direito privado para desempenhar as atividades exclusivas do Estado, as quais deteriam a prerrogativa de exercício do poder de polícia ${ }^{3}$. Segundo esse escopo, a redação enxuta seria por si só suficiente para superar o problema da criação irregular de fundações governamentais de direito privado nas situações em que o regime público seria obrigatório.

Na prática, porém, não se verificou a constituição de fundações estatais para exercer poderes tipicamente estatais, pois, após a promulgação da Constituição Federal de 1988, todas as fundações do governo federal passaram a ser fundações governamentais de direito público. O PLP n. 92/2007 surge como uma tentativa de reviver o modelo de fundação estatal de direito privado, então extinto "de fato" da esfera federal, para conferir flexibilidade de gestão.

Assim, a delimitação do âmbito das fundações de direito privado remete a um questionamento maior, atinente à definição do regime jurídico das fundações estatais de direito público e de direito privado. Assim, por uma segunda acepção, a finalidade do PLC n. 92/2007 seria superar a celeuma em torno da definição do regime jurídico das fundações estatais. O que significaria submeter uma fundação estatal ao regime de direito privado? Quais as implicações de ordem prática que o regime poderia determinar? O regime jurídico de direito privado seria hábil a conferir eficiência na prestação dos serviços públicos? Essas indagações levaram à redação dos dois substitutivos para estabelecer os contornos do modelo de fundação estatal de direito privado.

(3) Esta finalidade foi apresentada pelo Ministro do Planejamento quando da submissão do Projeto de Lei Complementar à Presidência da República. Segundo consta em sua fundamentação, "o Projeto prevê que somente poderá ser instituída para desempenho de atividades estatais que não sejam exclusivas de Estado, de forma a vedar a criação de entidade de direito privado para exercício de atividades em áreas que seja necessário o uso do poder de polícia". Disponível em: <http://www.camara.gov.br/sileg/integras/505853.pdf>. 
No âmbito da Comissão de Trabalho, de Administração e Serviço Público, dois substitutivos foram apresentados nos votos do Deputado Pedro Henry, também relator do PLP n. 92/2007, e da Deputada Alice Portugal(4). O primeiro substitutivo do Deputado Pedro Henry datado de maio de 2008 voltava-se à definição de diretrizes para orientar as leis específicas instituidoras de fundações estatais. Assim, o texto legal proposto passou a especificar o regime geral das fundações estatais, não se restringindo apenas a disciplinar as fundações governamentais de direito privado. Sua redação foi alterada por dois outros complementos de voto do substitutivo, ambos de junho de 2008.

Como resultado final, o substitutivo proposto pelo Deputado Pedro Henry determinou a possibilidade de as fundações governamentais serem instituídas sob o regime de direito público ou de direito privado, definiu as áreas de atuação das fundações governamentais e tratou da composição do patrimônio, da forma de extinção, de formação do quadro de pessoal e da licitação das fundações governamentais. Ainda, dispôs expressamente sobre o emprego de contratos pelas fundações governamentais, mais especificamente, dos contratos de gestão e de serviço. Por fim, o substitutivo em pauta acrescentou as áreas de ensino e pesquisa, formação profissional e cooperação técnica internacional dentre aquelas originalmente deferidas à fundação estatal de direito privado.

Com base no substitutivo do Deputado Pedro Henry, segundo substitutivo foi redigido e apresentado no voto em separado da Deputada Alice Portugal a respeito do PLP n. 92/2007. Este substitutivo se voltou à análise do regime das fundações governamentais de forma mais pormenorizada ao definir que as fundações com personalidade jurídica de direito privado são reguladas pelo Código Civil e legislação correlata. Outra particularidade do substitutivo corresponde à vedação de criação de fundações governamentais de direito privado para atuar nas áreas de ensino, pesquisa e ensino profissionalizante. A previsão expressa de revogação da Lei n. 9.790/1999, que disciplina as organizações da sociedade civil de interesse público, e da Lei n. 8.958/1994, relativa às fundações de apoio, consiste na mais saliente inovação deste segundo substitutivo ${ }^{(5)}$. O restante da redação é coincidente com o texto do primeiro substitutivo.

(4) Para uma análise comparativa do PLP n. 92/2007 e dos dois substitutivos apresentados no decorrer da tramitação do referido Projeto, vide o ANEXO I do presente artigo.

(5) Segundo a justificativa apresentada pela Deputada Alice Portugal, "este substitutivo apresenta uma cláusula revogatória da lei ordinária n. 9.790, de 1999, que trata da qualificação de pessoas jurídicas de direito privado, sem fins lucrativos, como as Organizações da Sociedade Civil de Interesse Público, as OSCIPs, e da Lei Ordinária n. 8.958, de 1994, que trata das relações entre as instituições federais de ensino superior e de pesquisa científica e tecnológica e das fundações de apoio. Com a criação das fundações de apoio de direito privado [leia-se fundação governamental de direito privado], torna-se desnecessária a contratação de OSCIPs e das fundações de apoio". 
Atualmente, o PLP n. 92/2007 encontra-se na Comissão de Constituição e Justiça, que recentemente aprovou por unanimidade parecer sobre a constitucionalidade do projeto. Os substitutivos ainda não ensejaram nenhuma emenda ao Projeto de Lei Complementar em análise.

É nesse cenário que se insere a fundação governamental de direito privado, objeto de estudo do presente artigo. O breve relato da tramitação legislativa do PLP n. 92/2007 teve por finalidade expor o grau de complexidade do tema que passa por três notórias dificuldades atinentes ao tema das fundações estatais, que serão enfrentadas do decorrer do trabalho: (i) precisão semântica do termo "fundação pública"; (ii) determinação do regime jurídico de direito privado; e (iii) promoção de eficiência às atividades administrativas pelo modelo das fundações governamentais de direito privado.

O presente artigo objetiva avaliar o PLP n. 92/2007, inclusive seus substitutos, quanto à sua capacidade de superar as expostas dificuldades com que se deparam as fundações governamentais de direito privado, modelo ainda em construção. Para tanto, far-se-á necessário adentrar em debates doutrinários, modelos de gestão e experiências jurídicas na medida do indispensável para proceder a um estudo centrado do Projeto de Lei Complementar em pauta pela perspectiva do Direito Administrativo.

\section{A INDETERMINAÇÃO SEMÂNTICA DE "FUNDAÇÃO PÚBLICA"}

O tema das fundações governamentais é considerado como um dos mais árduos no Direito Administrativo. Dúvidas quanto à delimitação deste ente da Administração Indireta e dificuldades operacionais imediatamente relacionadas à dicotomia regime jurídico de direito público e regime jurídico de direito privado fazem das fundações governamentais tema controverso. Muitos desses problemas se devem à imprecisão semântica do termo fundação pública ${ }^{(6)}$ no arcabouço normativo, na doutrina administrativista e na jurisprudência. A questão em pauta pode assim ser sintetizada: o atributo "público" é sinônimo de "estatal" ou de "regime jurídico de direito público"?

Sundfeld, Campos e Pinto noticiam que a redação original do DecretoLei n. 200/1967 ensejara uma linha interpretativa segundo a qual as fundações não integrariam a estrutura da Administração Pública; linha interpretativa essa fortemente combatida na Constituição Federal de $1988^{(7)}$. Para assina-

(6) Esse quadro de imprecisão semântica sobre o termo fundação pública já foi exposta por SUNDFELD, Carlos Ari; CAMPOS, Rodrigo Pinto de; PINTO, Henrique Motta. Regime jurídico das fundações governamentais. In: SUNDFELD, Carlos Ari; MONTEIRO, Vera Cristina Caspari (Coords.). Introdução ao direito administrativo. São Paulo: Saraiva, 2007. Cf., ainda, MODESTO, Paulo. As fundações estatais de direito privado e o debate sobre a nova estrutura orgânica da administração pública. Revista Trimestral de Direito Público - RTDP, São Paulo, v. 47, 2004.

(7) SUNDFELD, Carlos Ari; CAMPOS, Rodrigo Pinto de; PINTO, Henrique Motta. op. cit., p. 275. 
lar que as fundações eram parte da Administração Pública, diversos preceitos constitucionais fizeram referência expressa à fundação sem, contudo, observar um termo padronizado. Como consequência, quatro expressões foram empregadas pelo constituinte para se referir às fundações: "fundação", "fundação pública", fundações instituídas e mantidas pelo Poder Público e "fundações sob o controle estatal"(8).

No que tange especificamente ao PLP n. 92/2007, o termo 'fundação sem fins lucrativos de personalidade jurídica de direito privado' é tomado como sinônimo de fundação governamental de direito privado. Quando se desce aos substitutivos, a dificuldade semântica mostra-se ainda mais evidente. Pelo primeiro substitutivo, fundação governamental de direito privado é também designada de "fundação pública", "fundação pública com personalidade jurídica de direito privado" e "fundação pública destinada à prestação de serviços de acesso universal”. Além dessas expressões, o segundo substitutivo ainda emprega os termos "fundação pública com personalidade jurídica" e "fundação pública que atue na área de serviços social público" (sic) para se referir à mesma figura administrativa.

Consequência imediata do emprego, até mesmo caótico, das inúmeras derivações de "fundação governamental de direito privado" é a também imprecisão de seu respectivo regime jurídico. Embora esse problema não se evidencie no PLP n. 92/2007, os substitutivos impedem o reconhecimento das normas aplicáveis às fundações governamentais de direito privado, pois que marcados pela imprecisão terminológica.

Quando o primeiro substitutivo determina em seu art. $3^{\circ}, \S 2^{\circ}$, que "as receitas das 'fundações públicas' serão constituídas conforme dispuser a lei específica que autorizar a sua instituição e o seu estatuto", estará o comando dirigido às fundações estatais de direito público ou de direito privado? Tradicionalmente, entende-se que as fundações governamentais de direito privado têm sua criação autorizada por lei específica, ao passo que as de natureza pública devem ser instituídas pelo Poder Público diretamente por lei. Assim, pode-se afirmar a expressão "fundação pública" foi empregada no sentido de "fundação estatal de direito privado"? Toma-se um segundo exemplo. O dispositivo do $\S 4^{\circ}$ do mesmo artigo, segundo o qual "a 'fundação pública' estará sujeita à legislação federal sobre licitações e contratos administrativos", refere-se às fundações estatais de direito público ou de direito privado? É entendimento majoritário na doutrina administrativa que as entidades governamentais de

(8) Segundo Paulo MODESTO, "[s]ão adotadas nada menos que quatro formas de referência a fundações no texto constitucional: (a) 'fundação' (arts. 37, XVII e XIX, 39, § 7, 40, caput, 163, II, 167, VIII, e 202, §§ 3ำ e 4ํㅡㄹ da CF; e arts. 8ำ e 61 do ADCT); (b) 'fundação pública' (art. 39, caput, original, da CF, repristinado por decisão do STF; art. 19 do ADCT); (c) 'fundações instituídas e

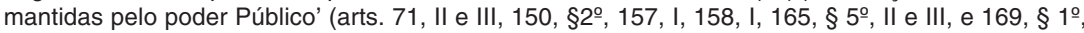
da CF; e arts. 18, 35, § 1, V, e 61 do ADCT); (d) 'fundações sob controle estatal' (art. 163, II, da CF e art. $8^{\circ}, \S 5^{\circ}$, da ADCT)". MODESTO, Paulo. op. cit., p. 52. 
direito privado - empresas estatais e fundações governamentais de direito privado - estão obrigadas a licitar, nos termos do art. 37, inciso XXI, da CF, mas não devem observância obrigatória à Lei n. 8.666/1993. Estaria o preceito a determinar a submissão das fundações estatais de direito privado à Lei Geral de Licitação (Lei n. 8.666/1993)?

As dúvidas se repetem no segundo substitutivo, principalmente pelo fato de sua construção ter sido pautada pelo primeiro, então tomado como modelo. Há, porém, um gravame neste documento, qual seja, o inadvertido emprego da expressão "fundação pública com personalidade jurídica" em substituição à "fundação pública com personalidade jurídica de direito privado", esta originária do primeiro substitutivo. Qual seria a sua tradução concreta? Ao dispor que "a 'fundação pública com personalidade jurídica' que atuar no âmbito do Sistema Único de Saúde obriga-se a observar seus princípios e diretrizes, previstos no art. 198 da Constituição Federal e no art. 7ํㅜㄴ da Lei n. 8.080, em especial os da regionalização, hierarquização, descentralização, comando único em cada esfera de governo e participação da comunidade" (art. 8º), o segundo substitutivo faz referência às fundações governamentais, às fundações governamentais de direito público ou às de direito privado?

Postas as considerações sobre a dificuldade terminológica atinente às fundações governamentais e demonstrado o impacto direto na conformação jurídica das mesmas, passa-se a analisar com maior profundidade a questão da personalidade jurídica.

\section{O REGIME DE DIREITO PRIVADO, O REGIME DE DIREITO PÚBLICO E O REGIME ADMINISTRATIVO MÍNIMO}

Dos debates doutrinários que seguiram após a implantação de um instituto típico do Direito Privado na Administração Pública - a fundação e da imprecisão semântica do termo "fundação pública" resultou um dos questionamentos de maior envergadura no Direito Administrativo brasileiro: qual é a natureza jurídica das fundações estatais? Há três correntes acerca da natureza jurídica das fundações governamentais na doutrina de Direito Administrativo:

a) por uma primeira vertente, toda e qualquer fundação instituída pelo Poder Público possui natureza privada, submetendo-se às regras de direito privado, exclusivamente ${ }^{(9)}$;

(9) Esse era o tratamento dado por Hely Lopes Meirelles até o advento da Constituição Federal de 1988. MEIRELLES, Hely Lopes. Direito administrativo brasileiro. 32. ed. São Paulo: Malheiros Ed., 2006. p. 355. 
b) as fundações criadas pelo Poder Público têm natureza autárquica, i. e., o termo "público" refere-se ao regime jurídico publicístico que a ela corresponde(10);

c) por fim, as fundações estatais podem igualmente assumir personalidade jurídica de direito público ou de direito privado, conforme o regime jurídico que a disciplinar ${ }^{(11)}$.

A Emenda Constitucional n. 19/1998, a Emenda da Reforma Administrativa delineada pelo extinto Ministério de Administração e Reforma do Estado (MARE), alterou o inciso XIX do art. $37^{12}$ para conferir-lhe a seguinte redação: "somente por lei específica poderá ser criada autarquia e autorizada a instituição de empresa pública, de sociedade de economia mista e de fundação, cabendo à lei complementar, neste último caso, definir as áreas de sua atuação."

Esta alteração do art. 37, inciso XIX, da Constituição Federal surge como uma tentativa de superação da imprecisão conceitual do termo 'fundação pública' quanto à admissão do regime de direito privado a reger a estrutura da fundação governamental. A supressão do termo "pública", interpretada pela primeira corrente doutrinária como "governamental", afirmaria com clareza a viabilidade de adoção tanto do regime de direito público quanto do regime de direito privado nas fundações estatais.

Parte-se do pressuposto de que a nova redação do art. 37, inciso XIX, da CF dada pela Emenda Constitucional n. 19/1998 permite a adoção indistinta do regime de direito público ou do regime de direito privado às fundações. As expressões "fundação governamental" e "fundação estatal', tomadas nesse artigo como sinônimas, serão, portanto, o gênero referente a todas as fundações integrantes da Administração Indireta. Como espécies, têm-se as fundações governamentais de direito público e as fundações governamentais de direito privado.

Criadas pelo Poder Público, as fundações governamentais submetem-se a uma disciplina constitucional própria, independentemente de se revestirem da forma pública ou privada. Certas normas constitucionais incidem sobre as fundações estatais simplesmente pelo fato de as mesmas serem entes integrantes da Administração (Indireta), tais quais os órgãos da Administra-

(10) Segundo Celso Antônio Bandeira de Mello, "[u]ma vez que as fundações públicas são pessoas de Direito Público de capacidade exclusivamente administrativa, resulta que são autarquias e que, pois, todo o regime jurídico dantes exposto, como o concernente às entidades autárquicas, aplicase-Ihes integralmente". MELLO, Celso Antônio Bandeira de. Curso de direito administrativo. 25. ed. São Paulo: Malheiros Ed., 2008. p. 186.

(11) Nessa linha perfilha Maria Sylvia Zanella Di Pietro. Direito administrativo. 21. ed. São Paulo: Atlas, 2008. p. 413.

(12) Essa é a redação original do art. 37, inciso XIX, da Constituição Federal: "somente por lei específica poderão ser criadas empresa pública, sociedade de economia mista, autarquia ou fundação pública." 
ção Direta, as empresas estatais (empresas públicas e sociedades de economia mista) e as autarquias. Dá-se o nome de regime administrativo míni$m o^{(13)}$ a esse conjunto de disposições constitucionais que compõe o núcleo comum aplicável a todos os órgãos e entes que integram a estrutura administrativa do Estado.

Essa é uma primeira consideração importante ao estudo do PLC n. 92/ 2007: ainda que sob a designação de fundação estatal de "direito privado", essas entidades devem observância ao regime administrativo mínimo, enquanto entes integrantes da estrutura da Administração Pública.

Porém, quais são os deveres impostos pelo regime administrativo mínimo às fundações governamentais?

No que tange à constituição das fundações governamentais, o art. 37, inciso XIX, da Constituição Federal exige requisitos específicos, quais sejam, previsão legal da criação e extinção das fundações estatais de direito público e autorização legal para criação e extinção de fundações governamentais de direto privado. Em relação à gestão das fundações governamentais, todas estão obrigadas a realizar licitação(14) e concurso público para composição de seus quadros de pessoal(15). Também se estende às fundações governamentais a vedação de acumulação de cargos, funções ou empregos públicos na Administração Direta ou Indireta(16). Quanto à fiscalização, sujeitam-se ao controle procedido pelo Tribunal de Contas ${ }^{(17)}$ e pelo Ministério Público, este em termos gerais.

Assim, atribuir o caráter público às fundações governamentais consiste em robustecer a disciplina jurídica de sua organização administrativa interna e do desenvolvimento de suas atividades, para além do regime administrativo mínimo. A disciplina mais detida das fundações governamentais de direito público decorre da aproximação desta figura com as autarquias, entes da Administração Indireta que possuem um regime jurídico muito próximo ao da Administração Direta(18), embora detenham personalidade jurídica e sejam especializadas para promoção de uma específica finalidade pública. As fundações governamentais de direito público aproximam-se das autarquias quanto ao regime jurídico (razão pela qual é comum deparar-se na literatura administrativista a expressão 'fundação-autárquica').

(13) Cf. SUNDFELD, Carlos Ari; CAMPOS, Rodrigo Pinto de; PINTO, Henrique Motta. op. cit., p. 271 e ss.

(14) Art. 37, inciso XXI, CF.

(15) Art. 37, inciso II, CF.

(16) Art. 37, inciso XVI, CF.

(17) Art. 70, parágrafo único, CF.

(18) Segundo Maria Sylvia Zanella Di Pietro, a particularidade da autarquia em relação aos demais órgãos que compõem a Administração Direta reside no relacionamento entre ambos os entes, pois a autarquia, especializada para desenvolvimento de uma específica atividade, detém o direito de desempenhá-la, inclusive opondo-se à Administração centralizada caso se evidenciem interferências que obstacularizem o cumprimento da função pública pela autarquia. DI PIETRO, Maria Sylvia Zanella. op. cit., p. 400. 
Tradicionalmente essa categoria de fundação é reconhecida pelas especificidades de seu regime jurídico, como sujeição à tutela pela Administração Direta (art. 19, Decreto-Lei n. 200/1967), inalienabilidade, imprescritibilidade e impenhorabilidade dos seus bens ${ }^{19}$, aplicação do sistema de precatórios para satisfação de dívidas decorrentes de processo judicial (art. 100, CF) e, dentre outros, cobrança de créditos por meio de execução fiscal. Ademais, adota-se o regime estatutário para reger, nos termos da Lei n. 8.112/1990, o pessoal da fundação governamental de direito público, que se submete às leis gerais do Direito Administrativo, como a Lei de Licitação (Lei n. 8.666/1993).

O regime jurídico das fundações governamentais de direito privado, por sua vez, assemelhar-se-iam ao das empresas estatais, fator que, a princípio, conferiria maior flexibilidade para desenvolvimento de suas competências administrativas, pois o arcabouço normativo das fundações governamentais de direito privado seria composto pelo regime administrativo mínimo e pelas normas de direito privado que não colidentes.

Dada a aproximação das fundações governamentais de direito privado às empresas estatais, algumas características são conferidas àquelas com base na disciplina constitucional das empresas públicas e sociedades de economia mista que, por expressa determinação do art. 173, §1으, inciso II, sujeitam-se ao "regime jurídico próprio das empresas privadas, inclusive quanto aos direitos e obrigações civis, comerciais, trabalhistas e tributários". Dessa forma, as fundações governamentais de direito privado são dotadas de patrimônio próprio, podem estabelecer regras próprias de licitação e contratação de suas atividades-meio (art. 173, §1ํ, inciso II, CF) e seus agentes públicos seguem o regime de emprego público disciplinado pela $\operatorname{CLT}^{(20)}$.

O ponto está em identificar o critério hábil a determinar a qualificação de uma fundação governamental como de direito público ou de direito privado. Não acreditamos que a tipificação da fundação governamental, pela simples nomenclatura em lei ou ato de criação, seja critério suficiente para caracterizar o tipo de fundação governamental quanto ao seu regime jurídico.

(19) Sobre os atributos dos bens públicos — inalienabilidade, impenhorabilidade, não oneração e imprescritibilidade - que marcam o regime jurídico especial a que estão submetidos e a correspondente indisponibilidade, Floriano de Azevedo Marques Neto afirma a necessidade de relativização da indisponibilidade, nos seguintes termos: "a indisponibilidade há de ser vista com alguma relatividade, pois há que se distinguir a indisponibilidade da função para o exercício da qual o bem serve como suporte da disponibilidade condicionada do próprio bem. $E$ isto se reflete em todos os atributos conformadores do regime jurídico dos bens públicos". MARQUES NETO, Floriano de Azevedo. O regime jurídico das utilidades públicas: função social e exploração econômica dos bens públicos. 2008. Tese (Livre-Docência) — Faculdade de Direito, Universidade de São Paulo, São Paulo, 2008. p. 354.

(20) Cf. GROTTI, Dinorá Adelaide Musetti. O regime jurídico das empresas estatais. In: WAGNER JUNIOR, Luiz Guilherme da Costa (Coord.). Direito público: estudos em homenagem ao professor Adilson de Abreu Dallari. Belo Horizonte: Del Rey, 2004. p. 141 e ss. 
Há necessidade de mapear o modelo de gestão da fundação governamental, i. e., identificar sua forma de organização interna e o modo de exercício das atividades, de onde será extraído o regime jurídico que a disciplina ${ }^{(21)}$. Constatada a presença de atributos públicos por meio da avaliação empírica da fundação governamental, que passa pela análise de todas as normas legais e regulamentares que a regem, deve a mesma ser qualificada como fundação governamental de direito público. Ao contrário, a identificação de atributos de direito privado no modelo de gestão da fundação governamental implica em sua categorização como fundação governamental de direito privado.

Assim, se em uma dada fundação governamental o regime de seu pessoal for estatutário, nos termos da Lei n. 8.112/1990, e for estabelecido na lei de criação, pode-se concluir que essa fundação será de direito público. Em sentido contrário, a fundação estatal de direito privado tem seu pessoal fundamentalmente em regime de emprego público, subordinado à CLT e o regime do pessoal é disciplinado por meio de ato interno.

\section{MODELOS DE GESTÃO CONTRATUAIS - ESTATISMO E PRIVATISMO NA PRESTAÇÃO DOS SERVIÇOS DE SAÚDE}

As fundações governamentais surgiram no Direito Administrativo brasileiro para superar o esgotamento do modelo autárquico decorrente da edição de diversas leis, normas e circulares que equiparavam a autarquia às repartições públicas ${ }^{(22)}$. As disfuncionalidades das repartições públicas repetidas, então, nas autarquias levaram o Governo Federal à adoção do modelo de fundação, lastreado no regime de direito privado:

[d]esencantados com o rumo que tomavam, entre nós, as autarquias, cada vez mais assemelhadas às repartições públicas, a partir de determinada época vimos, com satisfação, que o Govêrno, para o desempenho de certas atividades atípicas do Estado, estava lançando mão de uma entidade tomada de empréstimo ao Direito Civil — as fundações. ${ }^{(23)}$

(21) Embora o exercício do poder de autoridade seja recorrentemente empregado para caracterizar o regime jurídico de direito público, especialmente nos debates das agências reguladoras e dos conselhos de fiscalização profissional, este critério não se coloca nas fundações governamentais, dada sua natureza eminentemente prestacional. Cf. SUNDFELD, Carlos Ari; CAMPOS, Rodrigo Pinto de; PINTO, Henrique Motta. op. cit., p. 280.

(22) Homero SENNA e Clovis Zobaran MONTEIRO noticiam que a edição do Decreto-lei n. 5.527/1943 inaugurou o "processo de desautarquização" das autarquias brasileiras na medida em que lhes obrigava a adoção da classificação, nomenclatura, regime de salário de cargos e funções de extranumerário próprios da Administração Direta. Corroboraram para a aproximação das autarquias às estruturas burocráticas centrais a Lei n. 1.162/1950, que estabeleceu o mesmo regime de aposentadoria e pensão dos funcionários públicos aos funcionários autárquicos, e a Lei n. 1.711/ 1952, por meio da qual deferiu a aplicação "no que couber" do Estatuto dos funcionários públicos aos autárquicos. SENNA, Homero; MONTEIRO, Clovis Zobaran. Fundações no direito na administração. Rio de Janeiro: Fundação Getúlio Vargas, 1970. nota dos autores, 2.

(23) Id. Ibid. Nota dos autores, 3. 
Com a finalidade de conferir flexibilidade para a execução de tarefas que não se coadunam perfeitamente com o modelo das empresas estatais, foram instituídas as fundações no âmbito da Administração Pública com a edição do Decreto-Lei n. 200/1967. Não demorou muito para que o modelo se espraiasse pela estrutura administrativa do Estado a ponto de se cogitar uma "inflação de fundações" na década de 1970(24).

Irregularidades que embasaram "amarras normativas" e doutrinárias ${ }^{(25)}$ às fundações estatais, a tendência burocrática genuinamente nacional e a crise fiscal, que inviabilizou o financiamento orçamentário público destas entidades, paulatinamente conduziram à ineficiência deste modelo de gestão. Se a Reforma Administrativa de 1967 se viu às voltas da ineficiência do esquema autárquico de prestação de serviços sociais, a Reforma Administrativa de 1998 colocou em questionamento a forma de prestação direta das atividades pelo Estado.

Muito embora a forma de prestação de serviços pelo Estado já estivesse na agenda dos debates do Direito Administrativo e, mais ainda, da Administração Pública, a Reforma do Estado trouxe fôlego ao tema. A primazia do estatismo(26) na prestação de serviços, modelo este marcado pela prestação direta dos serviços pelo Estado por meio de sua estrutura administrativa, foi questionada e novas técnicas de fornecimento de utilidades pelo Estado foram normativamente concebidas. Além da forma de prestação indireta dos serviços por meio de associações público-privadas em sentido amplo (privatismo), a Reforma do Estado versou sobre técnicas de prestação direta de serviços pelo Poder Público que Ihe conferissem eficiência, sobretudo com recurso à experiência privada.

Nesse contexto, surgem as fundações de apoio.

Instituídas com a finalidade específica de colaborar com entes da Administração Pública, principalmente fundações governamentais e autarquias, as fundações de apoio consistem em um modelo amplamente utilizado pelo Estado na prestação de atividades educacionais e de saúde ${ }^{(27)}$. Trata-se de um modelo por meio do qual se firmam convênios entre a fundação de apoio e a entidade pública beneficiada no qual são estabelecidas as atividades e metas que a fundação de apoio deve satisfazer.

(24) Id. Ibid., p. 172.

(25) Saliente-se, nesse sentido, a ascensão da tese bastante disseminada da doutrina de Direito Administrativo de que as fundações estatais poderiam apenas seguir o regime de direito público.

(26) Fazemos referência ao antagonismo estatismo x privatismo constatado por SUNDFELD, Carlos Ari. O direito administrativo entre os clips e os negócios. In: ARAGÃO, Alexandre Santos de; MARQUES NETO, Floriano de Azevedo (Coords.). Direito administrativo e seus novos paradigmas. Belo Horizonte: Fórum, 2008. p. 88.

(27) Paralelamente às fundações de apoio instituídas pelos particulares, existem fundações de apoio criadas pelos próprios entes da Administração Pública, com seus próprios recursos. 
Os convênios ${ }^{(28)}$ têm sido caracterizados como um tipo contratual por meio do qual entes públicos ou privados, desde que detenham competências comuns, associam-se para alcançar objetivos convergentes, sem aperfeiçoamento de preço ou remuneração. Especificamente no que toca à associação público-privada nos convênios ${ }^{(29)}$, a figura contratual em pauta é empregada fundamentalmente para viabilizar a atividade pública de fomento. Por meio de convênios, o Poder Público cria incentivos (positivos) para que o particular proceda de determinado modo e alcance específica finalidade comum a ambos os entes associados. Por essa razão, vasto é o objeto do convênio: repasse de verbas, subvenções, financiamentos ${ }^{(30)}$, permissão de uso de equipamentos, materiais e imóveis, bem como uso de pessoal da Administração Pública. Os convênios são disciplinados pelo art. 116 da Lei n. 8.666/ 1993 e são passíveis de dispensa de licitação, nos termos do art. 24, inciso XXX, da Lei n. 8.666/1993. Saliente-se, por fim, que os convênios não implicam em delegação de serviços do parceiro público ao parceiro privado.

O tema das fundações de apoio não tem figurado dentre os centrais do Direito Administrativo. A pouca literatura existente sobre o tema volta-se, no entanto, a tecer duras críticas sobre o funcionamento das fundações de apoio no âmbito da Administração Pública. Dentre as várias críticas destinadas a esse modelo de gestão, está a "fuga para o Direito Privado", ou seja, o oportunístico emprego de um ente de colaboração particular para desenvolver as atividades ínsitas à Administração Pública sem se submeter ao regime administrativo mínimo, pois não integrante do aparato estatal(31). Ausência de licitação, contratação de pessoal sem realização de concurso público, confusão patrimonial entre o Poder Público e a fundação de apoio ou "apropriação indevida" de recursos públicos repassados mediante convênio ao ente particular, obstacularização do controle e outras tantas críticas resumem bem o conturbado quadro em que se inserem as fundações de apoio ${ }^{(32)}$.

Independentemente da pertinência das críticas acima mencionadas as quais devem ser ponderadas casuisticamente, conforme as peculiarida-

(28) Cf. MARQUES NETO, Floriano de Azevedo. Público e privado no setor de saúde. Revista de Direito Público da Economia - RDPE, Belo Horizonte, v. 9, p. 111 e ss., jan./mar. 2005.

(29) Os convênios podem ser celebrados, conforme exposto, entre entes públicos, ocasião em que se verifica a descentralização administrativa. Cf. art. 10 do Decreto-lei 200/1967 e art. 241 da CF, com redação conferida pela Emenda Constitucional n. 19/1998.

(30) Se pelo convênio o parceiro privado manejar recursos públicos, haverá controle pelo Tribunal de Contas, nos termos do art. 70 da CF. Para uma análise crítica do repasse de recursos públicos por meio de convênios, cf. SALINAS, Natasha Schimitt Caccia. Avaliação legislativa no Brasil: um estudo de caso sobre as normas de controle das transferências voluntárias de recursos públicos para entidades do terceiro setor. 2008. Dissertação (Mestrado) — Faculdade de Direito, Universidade de São Paulo, São Paulo, 2008.

(31) Cf. DI PIETRO, Maria Sylvia Zanella. Parcerias na administração pública. concessão, permissão, franquia, terceirização, parceria público-privada e outras formas. 5. ed. São Paulo: Atlas, 2005. p. 281 e ss.

(32) Sucessivas denúncias de irregularidades contribuíram para o incremento do discurso crítico em torno das fundações de apoio, a exemplo do recente caso FINATEC e da CPI das Sanguessugas. 
des do caso concreto - o fato é que a disseminação das fundações de apoio entre as diversas autarquias e fundações governamentais leva à constatação da atual inviabilidade do regime jurídico-administrativo para certas atividades sensíveis, como os serviços de saúde.

Tal qual delineado pela Constituição Federal e pelas normas legais e infralegais, o regime jurídico-administrativo brasileiro mostra-se eminentemente moralizante, o que não denota qualquer carga pejorativa. Pelo contrário. A estrutura do arcabouço normativo que rege as fundações governamentais confere igualdade de tratamento aos administrados que pretendam estabelecer vínculos administrativos com estes entes; o dever de licitar, por exemplo, assegura igualdade entre os licitantes no procedimento de contratação pública, ao passo que o dever de realizar concurso público permite que qualquer interessado possa integrar os quadros da Administração Pública, desde que aprovado em um procedimento objetivo e meritocrático. Outro ponto positivo deste arcabouço normativo que pode ser indicado é a conferência de garantias ao administrador público para que exerça suas atribuições de forma autônoma, sem ingerências políticas ou preferenciais.

Ocorre, porém, que a minúcia de tais condicionamentos nas normas que os disciplinam (e. g. Lei n. 8.666/1993 e Lei n. 8.112/1990) podem determinar a prestação de um serviço pelo Estado aquém das necessidades do usuário.

Sem adentrar no conceito de eficiência, o fato é que a obrigatoriedade de licitar, nos termos da Lei de Licitação, os procedimentos burocráticos envolvidos na prestação dos serviços, enfim, o regime jurídico-administrativo, impede que o Poder Público atue com a mesma flexibilidade notada no setor privado(33). O grau de impacto da incidência do regime jurídico-administrativo varia conforme o setor e o tipo de atividade desenvolvida: por vezes as "amarras constitucionais" pouco interferem no resultado final da prestação administrativa, por outras (tantas) elas obstacularizam o atingimento do ótimo do serviço público. A experiência do setor de saúde é rica no debate em torno dos efeitos da gestão pública da saúde.

Basicamente, argumenta-se que o excesso de burocracia na gestão pública da saúde impede a prestação de um serviço eficiente à população. Nesse sentido, em razão da incidência de certas normas não verificadas na prestação privada de saúde, o serviço público de saúde seria, em muitos

(33) Maria João Estorninho afirma que "esse carácter mais activo e mais interventor da Administração Pública é indissociável do seu recurso a novos métodos de actuação. Na verdade, esta actuação intervencionista do Estado nem sempre é exeqüível através da organização burocrática tradicional da Administração Pública, pelo que esta precisa de recorrer a novos modelos de organização e de actuação mais flexíveis e dinâmicos". ESTORNINHO, Maria João. A fuga para o direito privado: contributo para o estudo da actividade de direito privado da administração pública. Coimbra: Almedina, 1996. p. 39. 
casos, custoso, demorado e materialmente aquém da qualidade daquele notado no setor privado. Ainda, significativos óbices ao emprego e desenvolvimento de novas tecnologias seriam apontados como decorrentes da restrita margem de liberdade conferida ao administrador público para gerir.

Assim, embora as fundações de apoio sejam potencialmente hábeis a conferir eficiência na prestação das atividades de saúde, segundo essa linha de entendimento, o modelo foi exaurido com o fortíssimo controle exercido pelo Tribunal de Contas e pelo Ministério Público.

Se o modelo das fundações de apoio encontra-se esgotado, remanescem, porém, as dificuldades na gestão dos serviços públicos pelo Poder Público. Estudam-se modelos de gestão, dentre os quais se insere o PLC n. 92/2007. Além de definir as áreas de atuação das fundações governamentais de direito privado, o modelo de fundação governamental de direito privado destina-se também a substituir o de fundações de apoio, permanecendo, todavia em certa medida, flexibilidade para propiciar a almejada eficiência na prestação dos serviços pelo Estado.

Elucidativa é a manifestação do Ministro do Planejamento, Orçamento e Gestão Paulo Bernardo no Seminário "Aspectos Jurídicos da Fundação Estataf', realizado no dia 25 de junho de 2007 em Brasília, sobre o impacto da reformulação da forma de contratação e gestão propiciada pelo PLC n. 92/2007:

[e], evidentemente, isso vai servir para uma coisa fundamental, que é possibilitar aos gestores de saúde desses hospitais que nós mencionamos, e de várias outras instituições, possam dedicar e canalizar suas energias para resolver os problemas principais, que são os problemas da saúde que pacificam essa questão, quando o Tribunal de Contas e o Ministério Público vêm para cima da gente e querem que seja resolvido, e nós por dever de ofício, temos que defender o que estamos fazendo, até porque é a situação de fato criada, mas, de forma alguma achar que é razoável que esta situação perdure e que nós não temos que fazer nenhum tipo de mudança. É por isso que estamos tão empenhados na discussão dessa idéia. ${ }^{(34)}$

A fundação governamental corresponde a um modelo de gestão que pode ser empregado pela Administração Pública para prestação de seus

(34) Nesse sentido, também se pronunciou o Ministro da Saúde José Gomes Temporão no mesmo evento: "[g]rande parte da energia institucional e até da minha própria energia pessoal à frente do INCA, nós gastamos em longos processos de conflito com o Ministério Público, Tribunal de Contas, respondendo a inquéritos. Esse era o cotidiano. Essa estratégia se inviabilizou." SEMINÁRIO "ASPECTOS JURÍDICOS DA FUNDAÇÃO ESTATAL", 2007, Brasília. Brasília, Ministério do Orçamento, Planejamento e Gestão, Ministério da Saúde, Advocacia Geral da União e Instituto de Direito Sanitário, 2007. Disponível em: <http://www.fundacaoestatal.com.br/030.pdf>. Acesso em: 21 nov. 2008. p. 10. 
serviços, a exemplo do serviço de saúde. Evidencia-se, assim, margem de discricionariedade deferida ao administrador público para que conforme a modelagem mais adequada ao tipo de atividade que pretende desenvolver, contando, para tanto, com figuras estatais (empresas estatais, fundações governamentais e autarquias, por exemplo) e com figuras em parceria (convênio, contrato de gestão, termo de parceria e demais ajustes contratuais de parceria).

A finalidade do artigo não é expor à exaustão os possíveis tipos contratuais que a Administração Pública pode se valer para promover o serviço de saúde. No entanto, a análise da experiência de um específico modelo de gestão - o modelo das organizações sociais - será duplamente contributiva: permite que se evidencie o contratualismo como uma tendência na prestação dos serviços pelo Estado e demonstra as possíveis alternativas aos mesmos problemas que o PLP n. 92/2007 teve de enfrentar. O estudo dessa figura possibilitará, ao final, traçar importantes paralelos à proposta em questão.

\section{A EXPERIÊNCIA DAS ORGANIZAÇÕES SOCIAIS}

Terceiro setor, setor não-governamental, sociedade civil organizada e setor sem fins lucrativos são expressões rotineiramente empregadas como sinônimos de público não-estatal(35). O terceiro setor é notoriamente reconhecido de forma residual, ou seja, toda a entidade que não estiver contemplada no aparelho do Estado (primeiro setor) e que fugir da lógica de mercado (segundo setor) é abrangida pela ampla designação terceiro setor. A expressão "terceiro setor", contudo, não é amparada pelo Direito. Atualmente existem apenas dois revestimentos jurídicos para que as organizações integrantes do terceiro setor se consagrem como pessoas jurídicas de direito privado: as associações e as fundações. Os entes públicos não-estatais possuem uma finalidade social como objeto social, tal qual a promoção da saúde, a proteção ao meio ambiente ou o ensino.

Segundo o Plano Diretor da Reforma do Aparelho do Estado, as atividades desenvolvidas pelo Estado foram classificadas em atividades exclusivas e não-exclusivas. As atividades exclusivas foram articuladas em dois centros, quais sejam, o núcleo estratégico do Estado e as unidades descentralizadas ${ }^{(36)}$. Já as atividades não exclusivas foram caracterizadas como

(35) Cf. PEREIRA, Luiz Carlos Bresser; GRAU, Nuria Cunill (Coords.). Entre o Estado e o mercado: o público não-estatal. Rio de Janeiro: Fundação Getúlio Vargas, 1999.

(36) As atividades exclusivas do Estado alocadas em seu núcleo estratégico correspondem à elaboração de leis e políticas públicas, enquanto o campo das unidades descentralizadas abarca as atividades de execução de políticas públicas com utilização do poder coercitivo. Exercício do poder de polícia, regulamentação, fiscalização e desempenho do fomento são exemplos de atividades administrativas pertencentes a essa última categoria. Integram o núcleo estratégico do Estado os altos administradores públicos, assim considerados, no âmbito federal, o Presidente da República, 
serviços não-exclusivos e atividades de produção para o mercado. Para os serviços não-exclusivos, que juridicamente correspondem aos serviços sociais, foi determinada a estratégia de "transferir para o setor público nãoestatal estes serviços através de um programa de publicização".

As organizações sociais (OS) foram concebidas no bojo do Plano Nacional de Publicização - PNP - o qual se mobiliza pelo atendimento do cidadão-cliente, pela ênfase nos resultados e pelo controle social das ações ${ }^{(37)}$. Por meio do processo de pubicização, os serviços não-exclusivos passam da estrutura administrativa do Estado para os entes públicos nãoestatais qualificados como organizações sociais, nos termos da Lei n. 9.637/ $1998^{(38)}$, os quais se incumbem de prestar o serviço após celebração de contrato de gestão com a Administração Pública. Assim, as OS constituem em um título jurídico concedido a entes públicos não-estatais que atendam aos requisitos legais; qualificadas como OS, tais entes ficam autorizados a celebrar contrato de gestão com o Poder Público, instrumento jurídico elegido para proceder a publicização.

No âmbito federal, poderão requisitar o título de organização social "pessoas jurídicas de direito privado, sem fins lucrativos, cujas atividades sejam dirigidas ao ensino, à pesquisa científica, ao desenvolvimento tecnológico, à proteção e preservação do meio ambiente, à cultura e à saúde, atendidos os requisitos previstos nesta Lei’39). Os requisitos específicos para qualificação da entidade como organização social estão previstos no art. $2^{\circ}$ da Lei n. 9.637/1998: (i) comprovar registro de seu ato constitutivo com as cláusulas essenciais estipuladas no inciso(40); e (ii) haver aprovação de sua qualificação como OS pelo Ministro da pasta ou titular de órgão supervisor ou regulador da entidade.

$\mathrm{Na}$ qualidade de instrumento contratual atinente às OS, o contrato de gestão se destina à formação de parceria entre o Poder Público e as entida-

os Ministros de Estado, os Parlamentares, Juízes, Desembargadores, Ministros do STF e Procuradores da República. Já as unidades descentralizadas "inclui a polícia, os forças armadas, os órgãos de fiscalização e de regulamentação e os órgãos responsáveis pelas transferências de recursos, como o SUS e o sistema de auxílio desemprego". PEREIRA, Luiz Carlos Bresser. Reforma do Estado para a cidadania. São Paulo: Ed. 34, 1998. p. 102-103.

(37) Cf. art. 20 da Lei n. 9.637/1998.

(38) No caso do Estado de São Paulo, as organizações sociais são regidas pela Lei Complementar n. 846/1998.

(39) Art. 1ํㅡㄴ Lei n. 9.637/1998.

(40) São cláusulas essenciais do ato constitutivo da pretensa OS estipuladas no art. 2o, inciso I, da Lei n. 9.637/98: (a) natureza social e seus objetivos; (b) previsão da finalidade não-lucrativa; (c) disposição expressa de conselho de administração e de diretoria como órgãos de deliberação superior e de direção; (d) previsão de participação no órgão de deliberação superior de representantes do Poder Público e da sociedade civil; (e) definição da composição e atribuições da diretoria; (f) obrigatoriedade de publicação anual, no DOU, dos relatórios financeiro e de execução do contrato de gestão; (g) possibilidade de aceitação de novos associados, no caso de associações civis; $(\mathrm{h})$ proibição de distribuição de bens ou de parcela do patrimônio líquido; e (i) previsão de incorporação integral das doações e legados a ela destinada, bem como dos excedentes financeiros. 
des qualificadas como OS para execução das atividades definidas no art. 10 da Lei n. 9.637/1998 mediante fomento público. Os contornos do fomento do contrato de gestão são também delimitados na Lei das OS: destinação de recursos orçamentários e bens públicos mediante permissão de uso (art. 12), bem como cessão especial de servidor (art. 14). Dentre as principais características do contrato de gestão, saliente-se a especificação do programa de trabalho e as correspondentes metas (art. $7^{\circ}$, inciso I) e o controle por resultado procedido pelo órgão ou entidade supervisora especificado no art. $8^{\circ}$ da Lei federal das OS.

São, porém, as cláusulas essenciais do contrato de gestão estipuladas no art. 5 da Lei n. 9.637/1998 a chave do relativo sucesso que o modelo de organização social alcançou no desempenho de serviços sociais. Segundo o art. 6ำ da Lei das OS, o contrato de gestão deve discriminar as atribuições, responsabilidades e obrigações do Poder Público e da organização social contratada. Nesse sentido, 0 art. $7^{\circ}-$ obriga que o contrato de gestão verse sobre o programa de trabalho proposto pela OS, sobre as metas e os respectivos prazos para satisfação das mesmas, bem como sobre os critérios objetivos de avaliação de desempenho a serem utilizados, mediante indicadores de qualidade e produtividade.

A experiência das OS de saúde no Estado de São Paulo é positiva e merece, ainda que em breves linhas, ser relatada. Para finalizar dezessete obras inacabadas de construção de hospitais públicos, adotou-se o modelo de OS com o escopo de conferir um serviço de maior qualidade à população paulista carente com otimização dos gastos públicos.

Os novos hospitais colocaram a serviço do SUS um total de cerca de 4.300 leitos e tiveram produção anual em 2006, de cerca de 219 mil internações, 2,1 milhões de consultas ambulatoriais (com 23,6 mil cirurgias ambulatoriais), 23 mil procedimentos odontológicos, 1,8 milhão de consultas de urgência e 5,4 milhões de exames laboratoriais ${ }^{(41)}$.

No que tange aos custos, os números são reveladores quando comparados com os hospitais da Administração Direta da Secretaria de Estado de Saúde do Estado de São Paulo: em 2005, os hospitais gerenciados por OS obtiveram um gasto médio por saída de leito $24 \%$ menor que os hospitais da Administração Direta e, em 2006, 9,8\% menor ${ }^{(42)}$. Dados de 2007 mostram que dezenove hospitais, três ambulatórios, duas farmácias e um ambulatório de análises clínicas eram geridos por meio do modelo das OS.

(41) SECRETARIA DA SAÚDE DO ESTADO DE SÃO PAULO. Organizações Sociais da Saúde: a experiência exitosa de gestão pública de saúde do Estado de São Paulo, 2007. p. 10.

(42) Importante ressaltar que além das cláusulas essenciais previstas na Lei n. 9.637/1998, a Lei Complementar paulista $n$. 846/1998 prevê, especificamente para a área de saúde, a obrigatoriedade de o contrato de gestão prever que a OS de saúde prestará serviços exclusivamente aos usuários do SUS (art. 8으, inciso IV). 
O relativo sucesso do modelo das OS no Estado de São Paulo deve-se fundamentalmente à contratualização da prestação do serviço, ponto que será oportunamente analisado no item 7 do presente artigo.

\section{O REGIME DE DIREITO PRIVADO E EFICIÊNCIA NA PRESTAÇÃO DOS SERVIÇOS PELO ESTADO}

A mesma pergunta feita à época da Reforma Administrativa de 1967, que resultou no Decreto-Lei n. 200/1967, volta à tona nos dias atuais: as fundações governamentais de direito privado são hábeis a conferir eficiência à Administração Pública na prestação de serviços sociais?

Conforme exposto no início do artigo, um dos objetivos do PLC n. 92/ 2007 é conferir eficiência na prestação dos serviços concernentes às áreas especificadas em seu art. 1ํ, como se depreende dos debates parlamentares da correspondente tramitação legislativa. Diante da exaustão das fundações de apoio, a disciplina das fundações governamentais de direito privado ensejaria prestação de serviço público menos custoso e materialmente mais eficiente. Porém, bastaria a previsão do regime jurídico de direito privado para garantir eficiência no desenvolvimento das atividades prestacionais pelo Poder Público?

Uma fundação governamental de direito privado que não seja autossuficiente, i. e., que dependa de recursos públicos orçamentários para desenvolvimento de suas atividades, sujeita-se a uma série de limitações que repercutem imediatamente sobre a flexibilidade em sua gestão. O raciocínio efetuado no caso de dependência em empresa estatal pode ser transposto às fundações governamentais de direito privado, especialmente por estas terem seu regime jurídico próximo ao das empresas estatais. Dessa forma, a situação de dependência nas fundações governamentais de direito privado, situação essa reconhecida pela transferência de recursos públicos sem qualquer espécie de contrapartida para custeio de suas atividades ${ }^{(43)}$, impõe sensíveis limitações de ordem pública à gestão das atividades pela fundação.

As referidas limitações estão previstas na Lei Complementar n. 101/ 2000, a Lei de Responsabilidade Fiscal. Segundo seu art. 22, excedida a

(43) Conforme Carlos Ari Sundfeld e Rodrigo Pagani de Souza, "o conceito de empresa estatal dependente está ligado, essencialmente, à empresa que: (i) recebe recursos financeiros de seu controlador; (ii) destinados ao pagamento de suas despesas ordinárias (com pessoal, de custeio em geral ou de capital); (iii) de forma reiterada a cada exercício financeiro; (iv) sem necessidade de dar qualquer contrapartida específica; (v) de tal maneira que se verifica uma espécie de comunicação do seu orçamento com o orçamento do seu controlador, como se houvesse uma desconsideração de sua personalidade jurídica para os fins de sua gestão financeira e orçamentária". SUNDFELD, Carlos Ari; SOUZA, Rodrigo Pagani de. A superação da condição de empresa estatal dependente. In: OSÓRIO, Fábio Medina; SOUTO, Marcos Juruena Villela (Coords.). Direito administrativo: estudos em Homenagem a Diogo de Figueiredo Moreira Neto. Rio de Janeiro: Lumen Juris, 2006. p. 127. 
despesa total com pessoal em 95\% do limite, os órgãos e entes públicos não poderão conceder vantagem, aumento, reajuste ou adequação de remuneração do pessoal (inciso I), criar cargo, emprego ou função (inciso II), alterar a estrutura da carreira que determine aumento de despesa (inciso III), determinar provimento de cargo público, admissão ou contratação de pessoal (inciso IV) e contratação de hora extra (inciso V).

Essa ordem de limitações vai de encontro à flexibilidade almejada para as fundações governamentais de direito privado, além de aumentar significativamente o controle dessas entidades procedido pelo Tribunal de Contas. Assim, a questão da autossuficiência é fundamental na conformação do modelo de fundação governamental de direito privado. Sem prever instrumentos adequados a conferir autossuficiência econômica às fundações governamentais de direito privado, o PLC n. 92/2007 mostra-se insuficiente.

\section{A FUNDAÇÃO GOVERNAMENTAL DE DIREITO PRIVADO COMO MODELO DE GESTÃO CONTRATUAL}

O contrato, na qualidade de mecanismo privatista de prestação de serviços, é utilizado em diversas conformações para a prestação do serviço de saúde pelo Estado em parceria. Ressalte-se, primeiramente, que a própria Constituição Federal já prevê a possibilidade de a Administração Pública celebrar contrato com os particulares para prestação do serviço de saúde em seu art. $119, \S 1^{\circ}$, pelo qual "as instituições privadas podem participar de forma complementar do Sistema Único de Saúde, segundo diretrizes deste, mediante contrato de Direito Público ou convênio, tendo preferência as entidades filantrópicas e as sem fins lucrativos".

De fato, a experiência prática tem demonstrado o aumento do emprego de fórmulas contratuais na prestação dos serviços pelo Poder Público(44). Neste artigo, foi explorada uma figura contratual amplamente aproveitada pela Administração Pública paulista para prestação dos serviços de saúde, qual seja, o contrato de gestão. O aumento do uso de contratos pela Administração Pública insere-se em um cenário maior, compreendido pela consensualidade, em que provimentos destituídos de imperatividade (acordos administrativos) passam a ser considerados como alternativas de provimento administrativo(45).

(44) “(...) o facto de a intervenção do Estado assumir uma carácter geral faz com que a via da autoridade não seja sempre utilizável, a não ser que se transforme a Administração numa 'gigantesca máquina repressiva' e que, assim, passem antes a ser adoptadas novas vias 'contratualizadas' de actuação administrativa." ESTORNINHO, Maria João. op. cit., p. 94. Cf. também MEDAUAR, Odete. Direito administrativo moderno. 2. ed. São Paulo: Ed. Revista dos Tribunais, 2003. p. 210 e ss.

(45) Cf. DAMONTE, Roberto. Atti, accordi, convenzioni nella giustizia amministrativa. Pádua: CEDAM, 2002. p. 13. 
O contrato também pode ser aproveitado pelo PLP n. 92/2007 para (i) superar a eventual condição de dependência da fundação governamental de direito privado perante os recursos públicos; (ii) estabelecer obrigações e metas em prol de uma prestação de serviço mais eficiente; e (iii) disciplinar os contornos da incidência do regime administrativo mínimo.

Para conferir autonomia gerencial às fundações governamentais de direito privado, contrato cujo objeto seja a própria atividade desenvolvida pela fundação estatal pode ser celebrado com o Poder Público. A fundação governamental passaria, então, a receber contraprestação pelo serviço prestado aos usuários do serviço público em detrimento de repasses públicos, os quais terminariam por caracterizá-la como dependente. Dessa forma, a fundação governamental de direito privado prestaria o serviço estabelecido em seu ato de constituição aos cidadãos e receberia do Poder Público, como contraprestação pelo serviço prestado, quantia pecuniária a título de tarifa ${ }^{(46)}$.

No caso específico do serviço de saúde, as fundações governamentais de direito privado instituídas para desenvolvimento de atividades de saúde prestariam o serviço aos usuários e, comutativamente, receberiam contraprestação pelo Poder Público. Essa sistemática mostra-se especialmente interessante para as atividades de saúde que não sejam autossustentáveis, as quais demandam continuados repasses públicos para custeio das atividades-meio e fim $^{(47)}$.

Aproveitando-se da experiência dos contratos de gestão firmados pelas OS, a celebração de contrato entre o Poder Público e a fundação governamental de direito privado deve conter as cláusulas necessárias especificadas no art. $7^{\circ}$ da Lei n. 9.637/1998, fundamentais à promoção de eficiência na prestação do serviço ao cidadão. O contrato de prestação de serviço deve, portanto, dispor sobre (i) o programa de trabalho da fundação governamental de direito privado; (ii) estabelecer metas; (iii) prazos de execução; (iv) critérios objetivos de avaliação de desempenho da fundação estatal de direito privado; e (v) bem como limites e critérios para despesa com o pessoal das organizações sociais.

Ainda, o contrato pode ser interessante instrumento de disciplina da forma de incidência do regime administrativo mínimo, especialmente no que

(46) SUNDFELD, Carlos Ari; SOUZA, Rodrigo Pagani de. op. cit., p. 127. Alexandre Santos de Aragão aproxima essa espécie de contrato à concessão administrativa prevista na Lei n. 11.079/2004, a Lei de PPP. ARAGÃO, Alexandre Santos de. As fundações no direito público. In: SEMINÁRIO "ASPECTOS JURÍDICOS DA FUNDAÇÃO ESTATAL”, 2007, Brasília. Brasília, Ministério do Orçamento, Planejamento e Gestão, Ministério da Saúde, Advocacia Geral da União e Instituto de Direito Sanitário, 2007. Disponível em <http://www.fundacaoestatal.com.br/030.pdf>. Acesso em: 21 nov. 2008.

(47) MONTEIRO, Vera Cristina Caspari. A Fundação Estatal e a Gestão de Serviços Públicos Sociais. In: SEMINÁRIO “ASPECTOS JURÍDICOS DA FUNDAÇÃO ESTATAL”, 2007, Brasília. Brasília, Ministério do Orçamento, Planejamento e Gestão, Ministério da Saúde, Advocacia Geral da União e Instituto de Direito Sanitário, 2007. Disponível em: <http://www.fundacaoestatal.com.br/030.pdf>. Acesso em: 21 nov. 2008. 
concerne ao controle das fundações governamentais de direito privado. $\mathrm{O}$ desenho de cláusulas que estabeleçam metas precisas e critérios de avaliação objetivos potencializa o efetivo controle de resultados ${ }^{(48)}$. Assim, a fundação governamental de direito privado gozará de maior flexibilidade gerencial, pois o controle já se encontra "pautado pela meta", além de esta prática limitar a ingerência do Poder Público na execução do objeto contratual. A previsão de um mecanismo de avaliação interna também chamaria a atenção dos entes controladores para as especificidades das atividades desempenhadas pela fundação governamental de direito privado. Trata-se da 'domesticação do controle'.

Dessa forma, não basta ao PLC n. 92/2007 definir as áreas de atuação da fundação estatal de direito privado, mesmo porque o Decreto-Lei n. 200/ 1967 já cumpre essa funcionalidade em seu art. 5을 inciso IV, ao dispor que as fundações de direito privado serão criadas para "desenvolvimento de atividades que não exijam execução por órgãos ou entidades de direito público"(49). Há necessidade de previsão do instrumento contratual hábil a conferir autossuficiência à fundação governamental de direito privado que propicie flexibilidade em sua gestão e, dessa forma, eficiência na prestação dos serviços pelo Poder Público.

Sem previsão no PLP n. 92/2007, os substitutivos previram a figura do "contrato de serviço". Dessa forma, considerados os contratos celebrados com dispensa de licitação entre o Poder Público e a fundação estatal de direito privado, o contrato de serviço pode apresentar por objeto o fornecimento de bens produzidos pela entidade, a prestação de serviços e a realização de atividades inseridas em seu campo de atuação, vedada a subcontratação. Ambos os substitutivos delegam à lei que autorizar a instituição da fundação estatal de direito privado a regulamentação das finalidades, objetivos, responsabilidades, direitos, sistemática de avaliação de desempenho, estipulação de metas e "demais aspectos relacionados com a gestão e com os padrões de qualidade requeridos na prestação dos serviços e no desenvolvimento de suas atividades".

A inclusão de artigo nos substitutivos para prever expressamente o "contrato de serviço" é deveras positivo, especialmente para conferir segu-

(48) Para compreensão dos fundamentos teóricos administração de resultado e do foco no controle por resultados, cf. MOREIRA NETO, Diogo de Figueiredo. Quatro paradigmas do direito administrativo pós-moderno: legitimidade, finalidade, eficiência, resultados. Belo Horizonte: Fórum, 2008. p. 136 e ss. (49) In verbis, atentando-se ao fato de que o termo 'pública' foi empregado no sentido de 'governamental:

"Art. 5으, inciso IV - Fundação Pública - a entidade dotada de personalidade jurídica de direito privado, sem fins lucrativos, criada em virtude de autorização legislativa, para o desenvolvimento de atividades que não exijam execução por órgãos ou entidades de direito público, com autonomia administrativa, patrimônio próprio gerido pelos respectivos órgãos de direção, e funcionamento custeado pelos recursos da União e de outras fontes". Cf. ARAGÃO, Alexandre Santos de. op. cit. e MONTEIRO, Vera Cristina Caspari. op. cit. 
rança jurídica nas relações travadas pela fundação governamental de direito privado. Embora seja possível Poder Público e fundação governamental de direito privado celebrarem contrato desse jaez independentemente de expressa previsão legal, a previsão expressa dirime eventuais dúvidas ou argumentos de resistência que possam se colocar quanto à viabilidade jurídica dessa transação.

Contudo, o objeto desse contrato deve contemplar tão-somente bens e serviços que constituam o escopo da atividade desenvolvida pela fundação governamental de direito privado. Uma fundação governamental de direito privado que se volte à área da saúde não pode desenvolver serviços que escapem à sua finalidade institucional, como a prestação de serviços desportivos, por exemplo, sob pena de incorrer em inobservância ao dever de licitação determinado no art. 37, inciso XXI, da CF. Ademais, apenas a fundação governamental de direito privado que seja dependente de repasses públicos deve celebrar contrato de serviço, pois a finalidade última deste instrumento é superar a situação de dependência que resulta na incidência de condicionamentos contrários à almejada flexibilidade neste específico modelo.

Conforme os substitutivos, a contratação direta das fundações governamentais de direito privado pelo Poder Público para celebração do contrato de serviço se procederia por meio de dispensa de licitação. No entanto, o caso não é de dispensa de licitação, mas sim de inexigibilidade. Como indica o art. 37, inciso XXI, da CF, que impõe o dever de licitar a todos os órgãos e entes integrantes da Administração Pública, a licitação pode ser afastada nos "casos especificados na legislação"; casos esses que foram definidos na Lei n. 8.666/1993, mais especificamente nos seus arts. 24 e 25 que tratam, respectivamente, da dispensa e da inexigibilidade de licitação.

A lógica da dispensa de licitação é conferir ao administrador público faculdade de realizar, ou não, licitação nos casos expressamente determinados no art. 24 da Lei n. 8.666/1993. Parte-se da premissa de que se determinados objetos contratuais forem submetidos ao procedimento licitatório formalizado pela Lei n. 8.666/93 a Administração Pública pode não conseguir a contratação mais vantajosa; a licitação, nesses casos, é inviável $^{(50)}$. Dessa forma, entende-se o referido art. 24 como taxativo, ou seja, apenas nas situações especificadas em seus incisos caberá dispensa de licitação; qualquer outra dispensa que não se fundamente em um de seus incisos será ilegal.

Dentre as 28 hipóteses de dispensa de licitação, consta a dispensa para contratação de organizações sociais para celebração de contrato de

(50) JUSTEN FILHO, Marçal. Comentários à Lei de Licitações e Contratos Administrativos. 11. ed. São Paulo: Dialética, 2005. p. 232. 
prestação de serviço no inciso XXIV(51). O termo "organizações sociais" foi usado em sentido estrito pelo legislador, o que importa em considerar que a dispensa em comento se destina apenas aos entes públicos não-estatais qualificados como organizações sociais, nos termos da Lei n. 9.637/1998 (na esfera federal). Para estender-se ao PLP n. 92/2007, seria necessário que o projeto estabelecesse um artigo de modificação do teor do art. 24, inciso XXIV, da Lei n. 8.666/1993 para abranger também as fundações estatais de direito privado.

O caso pode se encerrar, ainda, em inexigibilidade de licitação, solução menos "traumática", mas igualmente plausível. A inexigibilidade colocase quando houver inviabilidade de competição, i. e., quando o objeto da contratação pública não admitir o esquema de concorrência entre os licitantes, típico dos procedimentos licitatórios. Na medida em que o contrato de serviço destina-se a superar a condição de dependência de uma dada fundação governamental de direito privado pela contratação do específico serviço por ela oferecido, proporcionando maior autonomia gerencial, orçamentária e financeira, não há espaço para competição entre a fundação dependente e outros entes interessados. Evidenciada a inviabilidade de competição, a contratação direta de fundação governamental de direito privado para prestação de serviço se processa por meio de inexigibilidade de licitação.

No que tange à conformação do contrato de serviço pela lei que autorizar a instituição da fundação governamental de direito privado, entendemos ser descabida a disciplina contratual pormenorizada por meio de lei. Primeiramente, os contornos do contrato de serviço dependem das especificidades do caso concreto, i. e., das particularidades da estrutura organizacional, das atividades desempenhadas pela fundação estatal de direito privado, bem como do cenário que elas se apresentam no específico momento da celebração do contrato. Apenas com o reconhecimento dessas particularidades será possível amoldar as cláusulas contratuais de forma mais consentânea com as características da fundação.

Consequentemente, a modelagem contratual não poderia ser adequadamente determinada antes de verificada a situação de dependência, as peculiaridades dessa condição e a definição da estratégia de superação da dependência, mesmo porque a situação de dependência não é inata à fundação. Se algumas atividades são, pela sua natureza, dependentes do repasse de recursos públicos, outras talvez passem a depender de recursos orçamentários apenas no futuro ou, ainda, nunca serão dependentes.

(51) A dispensa de licitação referida nos substitutivos para os casos de celebração de contrato de serviço fundamenta-se no art. 24, inciso XXIV, da Lei n. 8.666/1993, acrescentado pela Lei $n$. 9.648/1998: "Art. 24. É dispensável a licitação: (...) XXIV — para a celebração de contratos de prestação de serviços com as organizações sociais, qualificadas no âmbito das respectivas esferas de governo, para atividades contempladas no contrato de gestão." 
Ressalte-se que tais contratos de serviço são de trato contínuo (contratos relacionais), pois perduram por largo lapso temporal principalmente no caso das fundações governamentais de direito privado que desenvolvam atividades dependentes por natureza. Natural que com o passar do tempo as condições que determinaram o desenho do contrato mudem, como o advento de nova técnica resultante de significativa inovação tecnológica que eleve o padrão de qualidade do serviço prestado ou a supressão de uma meta por conta de fato imprevisível. Os contratos diferidos demandam um grau de flexibilidade que a lei e seu processo legislativo não conferem. Como a alteração de lei se dá mediante a edição de uma nova lei (princípio da reciprocidade de formas), o ideal é deixar que as próprias partes contratantes acomodem no contrato e renegociem abertamente o contrato, da forma que reputarem mais satisfatória às finalidades públicas, dentro da legalidade e atendido o regime administrativo mínimo.

Ao lado da figura do contrato de serviço, foi previsto nos substitutivos o contrato de gestão como mecanismo contratual de ampliação da autonomia gerencial, orçamentária ou financeira da fundação estatal de direito privado(52). Para tanto, o contrato de gestão teria por objeto "a prestação de serviços e a fixação de metas de desempenho para a entidade". Nota-se que o objeto do contrato de gestão é coincidente com o do contrato de serviço, ou seja, ambas as figuras contratuais possuem a mesma funcionalidade. Para fins de padronização e coerência normativa, mostra-se interessante a previsão de um único instrumento contratual dirigido à disciplina da prestação de serviços pela fundação estatal de direito privado.

Por fim, saliente-se que contrato de gestão não deve funcionar como mecanismo de promoção de autonomia orçamentária, gerencial e financeira às fundações não dependentes, conforme exposto quando da análise do contrato de serviço ${ }^{(53)}$.

\section{CONSIDERAÇÕES FINAIS}

Ainda um modelo em construção, as fundações governamentais de direito privado consistem na nova aposta governamental para conferir efici-

(52) Cf. OLIVEIRA, Gustavo Henrique Justino de. Contrato de gestão e modernização da administração pública brasileira. Revista Brasileira de Direito Público - RBDP, Belo Horizonte, v. 10, p. 207 e ss., jul./set. 2005. O 'contrato de gestão', neste caso, corresponde ao previsto no art. $37, \S 8^{\circ}$, da CF, que não se confunde com o 'contrato de gestão' previsto no art. $5^{\circ}$ da Lei n. 9.637/1998.

(53) O raciocínio depreendido para as empresas estatais dependentes por Carlos Ari Sundfeld e Rodrigo Pagani de Souza pode ser aproveitado para as fundações governamentais de direito privado: "[p]or certo, não faria sentido a celebração do tipo de contrato de gestão a que se refere esse preceito (isto é, o contrato de gestão para ampliar autonomia) ser feita com uma empresa estatal não dependente. Isso porque tal empresa já é inteiramente autônoma, nada mais se lhe podendo oferecer nesse sentido. Quem pode ser beneficiada por um contrato de gestão desse tipo é, então, por óbvio, aquela empresa atingida pela limitação de sua autonomia: justamente a empresa estatal dependente". SUNDFELD, Carlos Ari; SOUZA, Rodrigo Pagani de. op. cit., p. 250. 
ência na gestão e prestação de serviços não-exclusivos do Estado, em especial o serviço de saúde. O Projeto de Lei Complementar em tramitação na Câmara dos Deputados (PLP n. 92/2007) se encontra às voltas com clássicas questões que acompanham as fundações estatais desde momento que este instituto, típico do Direito Privado, foi primeiramente empregado na Administração Pública brasileira.

No que tange à indeterminação semântica do termo 'fundação pública', que repercute imediatamente na caracterização dos regimes jurídicos de direito público e de direito privado, nota-se que o PLP n. 92/2007 não conseguiu superar essa celeuma, principalmente quando analisados os dois substitutivos ainda pendentes de votação. Todavia, positiva a previsão expressa de que as fundações governamentais tanto podem ser regidas pelo regime de direito público quanto pelo regime de direito privado.

Definir as áreas de atuação das fundações governamentais de direito privado é insuficiente para garantir eficiência ao modelo de gestão em comento. Caso essas entidades sejam dependentes do repasse de recursos públicos para manter-se em funcionamento e realizar suas atividades-fim, haverá redução da flexibilidade que elas possuem quando comparadas com as fundações autárquicas ante a incidência de normas de ordem pública constritivas de sua autonomia gerencial.

Para conferir autonomia gerencial às fundações governamentais dependentes do repasse de recursos públicos, a figura do contrato pode ser bem-vinda. A experiência positiva do contrato de gestão nas organizações sociais paulistas confere diretrizes para delinear a estrutura desse contrato que, basicamente, determina que a fundação governamental de direito privado terá direito à contraprestação pelo Poder Público pela prestação de suas atividades aos cidadãos. A formalização deste contrato de prestação de serviço pode se dar aos moldes do contrato de gestão ou a lei pode estipular algum outro instrumento específico de semelhante finalidade.

O ponto do artigo está em visualizar as fundações governamentais de direito privado como um modelo de gestão contratual, cuja eficiência condiciona-se à clareza e objetividade da estipulação das metas e critérios de avaliação de desempenho. O PLP n. 92/2007 precisa ser apurado para que, além de prever essa figura contratual, confira a abertura necessária para que a modelagem do contrato atente às especificidades da atividade desenvolvida pela fundação governamental de direito privado e às mudanças do cenário em que ele se insere.

Para desenvolvimento de suas atividades, conta a Administração Pública com variados modelos de gestão estatais ou privatistas, dentre eles, a fundação governamental de direito privado. Embora já seja juridicamente viável, independentemente da existência de lei complementar dispondo sobre as correspondentes áreas de atuação, caminha o PLP n. 92/2007 para 
dar os contornos à fundação governamental de direito privado. Com o escopo de garantir eficiência ao funcionamento desse modelo, o contrato deve figurar como elemento central dessa disciplina jurídica.

\section{REFERÊNCIAS BIBLIOGRÁFICAS}

ARAGÃO, Alexandre Santos de. As fundações no direito público. In: SEMINÁRIO "ASPECTOS JURÍDICOS DA FUNDAÇÃO ESTATAL", 2007, Brasília. Brasília, Ministério do Orçamento, Planejamento e Gestão, Ministério da Saúde, Advocacia Geral da União e Instituto de Direito Sanitário, 2007. Disponível em $<$ http://www.fundacaoestatal.com.br/030.pdf>. Acesso em: 21 nov. 2008.

DAMONTE, Roberto. Atti, accordi, convenzioni nella giustizia amministrativa. Pádua: CEDAM, 2002.

DI PIETRO, Maria Sylvia Zanella. Direito administrativo. 21. ed. São Paulo: Atlas, 2008.

Parcerias na administração pública. concessão, permissão, franquia, terceirização, parceria público-privada e outras formas. 5. ed. São Paulo: Atlas, 2005.

ESTORNINHO, Maria João. A fuga para o direito privado: contributo para o estudo da actividade de direito privado da administração pública. Coimbra: Almedina, 1996.

GROTTI, Dinorá Adelaide Musetti. O regime jurídico das empresas estatais. In: WAGNER JUNIOR, Luiz Guilherme da Costa (Coord.). Direito público: estudos em homenagem ao professor Adilson de Abreu Dallari. Belo Horizonte: Del Rey, 2004. p. 125-179.

JUSTEN FILHO, Marçal. Comentários à Lei de Licitações e Contratos Administrativos. 11. ed. São Paulo: Dialética, 2005.

MARQUES NETO, Floriano de Azevedo. Público e privado no setor de saúde. Revista de Direito Público da Economia - RDPE, Belo Horizonte, v. 9, jan./mar. 2005.

O regime jurídico das utilidades públicas: função social e exploração econômica dos bens públicos. 2008. Tese (Livre-Docência) — Faculdade de Direito, Universidade de São Paulo, São Paulo, 2008.

MEDAUAR, Odete. Direito administrativo moderno. 2. ed. São Paulo: Ed. Revista dos Tribunais, 2003.

MEIRELLES, Hely Lopes. Direito administrativo brasileiro. 32. ed. São Paulo: Malheiros Ed., 2006.

MELLO, Celso Antônio Bandeira de. Curso de direito administrativo. 25. ed. São Paulo: Malheiros Ed., 2008. 
MODESTO, Paulo. Convênio entre entidades públicas executado por fundação de apoio: serviços de saúde - conceito de serviço público e serviço de relevância pública. Revista Trimestral de Direito Público - RTDP, São Paulo, v. 28, 1999.

As fundações estatais de direito privado e o debate sobre a nova estrutura orgânica da administração pública. Revista Trimestral de Direito Público - RTDP, São Paulo, v. 47, 2004.

MONTEIRO, Vera Cristina Caspari. A Fundação Estatal e a Gestão de Serviços Públicos Sociais. In: SEMINÁRIO "ASPECTOS JURÍDICOS DA FUNDAÇÃO ESTATAL”, 2007, Brasília. Brasília, Ministério do Orçamento, Planejamento e Gestão, Ministério da Saúde, Advocacia Geral da União e Instituto de Direito Sanitário, 2007. Disponível em: <http://www.fundacaoestatal.com.br/ 030.pdf>. Acesso em: 21 nov. 2008.

MOREIRA NETO, Diogo de Figueiredo. Quatro paradigmas do direito administrativo pós-moderno: legitimidade, finalidade, eficiência, resultados. Belo Horizonte: Fórum, 2008.

OLIVEIRA, Gustavo Henrique Justino de. Contrato de gestão e modernização da administração pública brasileira. Revista Brasileira de Direito Público - RBDP, Belo Horizonte, v. 10, jul./set. 2005.

PEREIRA, Luiz Carlos Bresser. Reforma do Estado para a cidadania. São Paulo: Ed. 34, 1998.

; GRAU, Nuria Cunill (Coords.). Entre o Estado e o mercado: o público não-estatal. Rio de Janeiro: Fundação Getúlio Vargas, 1999.

SALINAS, Natasha Schimitt Caccia. Avaliação legislativa no Brasil: um estudo de caso sobre as normas de controle das transferências voluntárias de recursos públicos para entidades do terceiro setor. 2008. Dissertação (Mestrado) - Faculdade de Direito, Universidade de São Paulo, São Paulo, 2008.

SECRETARIA DA SAÚDE DO ESTADO DE SÃO PAULO. Organizações Sociais da Saúde: a experiência exitosa de gestão pública de saúde do Estado de São Paulo, 2007.

SEMINÁRIO “ASPECTOS JURÍDICOS DA FUNDAÇÃO ESTATAL”, 2007, Brasília. Brasília, Ministério do Orçamento, Planejamento e Gestão, Ministério da Saúde, Advocacia Geral da União e Instituto de Direito Sanitário, 2007. Disponível em: <http://www.fundacaoestatal.com.br/030.pdf>. Acesso em: 21 nov. 2008.

SENNA, Homero; MONTEIRO, Clovis Zobaran. Fundações no direito na administração. Rio de Janeiro: Fundação Getúlio Vargas, 1970.

SUNDFELD, Carlos Ari. O direito administrativo entre os clips e os negócios. In: ARAGÃO, Alexandre Santos de; MARQUES NETO, Floriano de Azevedo (Coords.). Direito administrativo e seus novos paradigmas. Belo Horizonte: Fórum, 2008. 
; CAMPOS, Rodrigo Pinto de; PINTO, Henrique Motta. Regime jurídico das fundações governamentais. In: SUNDFELD, Carlos Ari; MONTEIRO, Vera Cristina Caspari (Coords.). Introdução ao direito administrativo. São Paulo: Saraiva, 2007.

; SOUZA, Rodrigo Pagani de. A superação da condição de empresa estatal dependente. In: OSÓRIO, Fábio Medina; SOUTO, Marcos Juruena Villela (Coords.). Direito administrativo: estudos em Homenagem a Diogo de Figueiredo Moreira Neto. Rio de Janeiro: Lumen Juris, 2006.

\section{Anexo I - PLP n. 92/2007}

\section{Projeto de Lei Complementar}

Regulamenta o inciso XIX do art. 37 da Constituição Federal, parte final, para definir as áreas de atuação de fundações instituídas pelo poder público.

O Congresso Nacional decreta:

Art. 1 Poderá, mediante lei específica, ser instituída ou autorizada a instituição de fundação sem fins lucrativos, integrantes da administração pública indireta, com personalidade jurídica de direito público ou privado, nesse último caso, para o desempenho de atividade estatal que não seja exclusiva do Estado, nas seguintes áreas:

I - saúde;

II - assistência social;

III - cultura;

IV - desporto;

$\mathrm{V}$ - ciência e tecnologia;

$\mathrm{VI}$ - meio ambiente;

VII - previdência complementar do servidor público, de que trata o art. 40, §§ 14 e 15, da Constituição;

VIII - comunicação social; e

IX - promoção do turismo nacional.

$\S 1^{\circ}$ Para os efeitos desta Lei Complementar, compreendem-se na área de saúde também os hospitais universitários federais.

$\S 2^{\circ} \mathrm{O}$ encaminhamento de projeto de lei para autorizar a instituição de hospital universitário federal sob a forma de fundação de direito privado será precedido de manifestação pelo respectivo conselho universitário.

Art. $2^{\circ}$ Esta Lei Complementar entra em vigor na data de sua publicação. 


\section{Anexo II - Tabela comparativa entre o PLP n. 92/2007 e seus substitutos}

\begin{tabular}{|c|c|c|c|}
\hline & PLP n. 92/2007 & $\begin{array}{c}\text { Primeiro } \\
\text { substitutivo }\end{array}$ & $\begin{array}{c}\text { Segundo } \\
\text { substitutivo }\end{array}$ \\
\hline Criação & $\begin{array}{l}\text { Lei específica pode- } \\
\text { rá instituir ou autori- } \\
\text { zar a instituição de } \\
\text { fundação sem fins } \\
\text { lucrativos }\end{array}$ & $\begin{array}{l}\text { Lei específica pode- } \\
\text { rá instituir ou autori- } \\
\text { zar a instituição de } \\
\text { fundação sem fins } \\
\text { lucrativos }\end{array}$ & $\begin{array}{l}\text { Lei específica pode- } \\
\text { rá autorizar a institui- } \\
\text { ção de fundação sem } \\
\text { fins lucrativos }\end{array}$ \\
\hline $\begin{array}{l}\text { Personalidade } \\
\text { jurídica }\end{array}$ & $\begin{array}{l}\text { Personalidade jurídi- } \\
\text { ca de direito público } \\
\text { ou de direito privado }\end{array}$ & $\begin{array}{l}\text { Personalidade jurídi- } \\
\text { ca de direito público } \\
\text { ou de direito privado }\end{array}$ & $\begin{array}{l}\text { Personalidade jurídi- } \\
\text { ca de direito público } \\
\text { ou de direito privado }\end{array}$ \\
\hline Atividade estatal & $\begin{array}{l}\text { A fundação de direi- } \\
\text { to privado poderá } \\
\text { desempenhar ape- } \\
\text { nas atividades esta- } \\
\text { tais não exclusivas } \\
\text { do Estado }\end{array}$ & $\begin{array}{l}\text { A fundação de direi- } \\
\text { to privado poderá } \\
\text { desempenhar ape- } \\
\text { nas atividades esta- } \\
\text { tais não exclusivas } \\
\text { do Estado }\end{array}$ & $\begin{array}{l}\text { A fundação de direito } \\
\text { privado poderá de- } \\
\text { sempenhar apenas } \\
\text { atividades estatais não } \\
\text { exclusivas do Estado } \\
\text { ou que, pela relevân- } \\
\text { cia e interesse público, } \\
\text { o Estado atue sem a } \\
\text { presença complemen- } \\
\text { tar ou concomitante da } \\
\text { iniciativa privada }\end{array}$ \\
\hline $\begin{array}{l}\text { Definição de ativi- } \\
\text { dade exclusiva de } \\
\text { Estado }\end{array}$ & $X X X$ & $\begin{array}{l}\text { Atividade que exige o } \\
\text { exercício do poder de } \\
\text { polícia ou que, pela } \\
\text { relevância e interes- } \\
\text { se público, o Estado } \\
\text { atue sem a presença } \\
\text { complementar ou } \\
\text { concomitante da inici- } \\
\text { ativa privada }\end{array}$ & $X X X$ \\
\hline $\begin{array}{l}\text { Áreas de atuação } \\
\text { da fundação go- } \\
\text { vernamental de di- } \\
\text { reito público }\end{array}$ & $\begin{array}{l}\text { Saúde (incluídos os } \\
\text { hospitais federais) - } \\
\text { assistência social - } \\
\text { cultura - desporto } \\
- \text { ciência e tecnolo- } \\
\text { gia - ensino e pes- } \\
\text { quisa - meio ambi- } \\
\text { ente - previdência } \\
\text { complementar do } \\
\text { servidor público - } \\
\text { comunicação social } \\
\text { - promoção do tu- } \\
\text { rismo nacional - for- } \\
\text { mação profissional } \\
\text { - cooperação técni- } \\
\text { ca internacional }\end{array}$ & $\begin{array}{l}\text { Saúde - assistên- } \\
\text { cia social - cultura } \\
\text { - desporto - ciên- } \\
\text { cia e tecnologia - } \\
\text { ensino e pesquisa- } \\
\text { meio ambiente - } \\
\text { previdência comple- } \\
\text { mentar do servidor } \\
\text { público - comuni- } \\
\text { cação social - pro- } \\
\text { moção do turismo } \\
\text { nacional - forma- } \\
\text { ção profissional - } \\
\text { cooperação técnica } \\
\text { internacional }\end{array}$ & $X X X$ \\
\hline
\end{tabular}




\begin{tabular}{|c|c|c|c|}
\hline & PLP n. 92/2007 & $\begin{array}{c}\text { Primeiro } \\
\text { substitutivo }\end{array}$ & $\begin{array}{l}\text { Segundo } \\
\text { substitutivo }\end{array}$ \\
\hline $\begin{array}{l}\text { Áreas de atuação } \\
\text { da fundação go- } \\
\text { vernamental de di- } \\
\text { reito privado }\end{array}$ & $\begin{array}{l}\text { Saúde (incluídos os } \\
\text { hospitais federais) - } \\
\text { assistência social - } \\
\text { cultura - desporto } \\
\text { - ciência e tecnolo- } \\
\text { gia - meio ambiente } \\
\text { - previdência com- } \\
\text { plementar do servi- } \\
\text { dor público - comu- } \\
\text { nicação social - } \\
\text { promoção do turismo } \\
\text { nacional }\end{array}$ & $\begin{array}{l}\text { Saúde (incluídos os } \\
\text { hospitais federais) } \\
- \text { assistência soci- } \\
\text { al - cultura - des- } \\
\text { porto - ciência e } \\
\text { tecnologia - ensino } \\
\text { e pesquisa - meio } \\
\text { ambiente - previ- } \\
\text { dência complemen- } \\
\text { tar do servidor pú- } \\
\text { blico - comunica- } \\
\text { ção social - promo- } \\
\text { ção do turismo na- } \\
\text { cional - formação } \\
\text { profissional - coo- } \\
\text { peração técnica in- } \\
\text { ternacional }\end{array}$ & $\begin{array}{l}\text { Saúde - assistência } \\
\text { social - cultura - } \\
\text { desporto - ciência e } \\
\text { tecnologia - meio } \\
\text { ambiente - previ- } \\
\text { dência complementar } \\
\text { do servidor público - } \\
\text { comunicação social } \\
\text { - promoção do turis- } \\
\text { mo nacional - coo- } \\
\text { peração técnica in- } \\
\text { ternacional }\end{array}$ \\
\hline $\begin{array}{l}\text { Patrimônio da fun- } \\
\text { dação "pública" }\end{array}$ & $X X X$ & $\begin{array}{l}\text { Patrimônio próprio: } \\
\text { bens móveis e imó- } \\
\text { veis, valores, direitos } \\
\text { e outros bens que lhe } \\
\text { forem destinados ou } \\
\text { que adquirir com re- } \\
\text { ceita própria }\end{array}$ & $\begin{array}{l}\text { Patrimônio próprio: } \\
\text { bens móveis e imó- } \\
\text { veis, valores, direitos } \\
\text { e outros bens que lhe } \\
\text { forem destinados ou } \\
\text { que adquirir com re- } \\
\text { ceita própria }\end{array}$ \\
\hline $\begin{array}{l}\text { Receitas da funda- } \\
\text { ção "pública" }\end{array}$ & $X X X$ & $\begin{array}{l}\text { Conforme disposi- } \\
\text { ção da lei específica } \\
\text { e seu estatuto: dota- } \\
\text { ções consignadas } \\
\text { na lei orçamentária } \\
\text { anual; auxílios e sub- } \\
\text { venções concedidas } \\
\text { por entidades de di- } \\
\text { reito público ou de } \\
\text { direito privado; ren- } \\
\text { das produzidas de } \\
\text { seus bens ou ativi- } \\
\text { dades; contribuições } \\
\text { provenientes de en- } \\
\text { tidades nacionais, } \\
\text { estrangeiras ou in- } \\
\text { ternacionais; saldos } \\
\text { financeiros dos exer- } \\
\text { cícios; outras ren- } \\
\text { das eventuais }\end{array}$ & $\begin{array}{l}\text { Conforme disposição } \\
\text { da lei específica e seu } \\
\text { estatuto: dotações } \\
\text { consignadas na res- } \\
\text { pectiva lei orçamentá- } \\
\text { ria do ente federativo; } \\
\text { auxílios e subvenções } \\
\text { concedidas por enti- } \\
\text { dades de direito públi- } \\
\text { co ou de direito priva- } \\
\text { do; rendas produzi- } \\
\text { das de seus bens ou } \\
\text { atividades; contribui- } \\
\text { ções provenientes de } \\
\text { entidades nacionais, } \\
\text { estrangeiras ou inter- } \\
\text { nacionais; saldos fi- } \\
\text { nanceiros dos exer- } \\
\text { cícios; outras rendas } \\
\text { eventuais }\end{array}$ \\
\hline
\end{tabular}




\begin{tabular}{|c|c|c|c|}
\hline & PLP n. 92/2007 & $\begin{array}{c}\text { Primeiro } \\
\text { substitutivo }\end{array}$ & $\begin{array}{l}\text { Segundo } \\
\text { substitutivo }\end{array}$ \\
\hline $\begin{array}{l}\text { Fundação "públi- } \\
\text { ca" e licitação }\end{array}$ & $X X X$ & \begin{tabular}{|l} 
Aplicação da Lei n. \\
$8.666 / 1993$
\end{tabular} & $\begin{array}{l}\text { Aplicação da Lei n. } \\
8.666 / 1993\end{array}$ \\
\hline $\begin{array}{l}\text { Admissão de pes- } \\
\text { soal permanente }\end{array}$ & $x x x$ & $\begin{array}{l}\text { Necessidade de rea- } \\
\text { lizar concurso públi- } \\
\text { co, qualquer que } \\
\text { seja o regime jurídi- } \\
\text { co da fundação go- } \\
\text { vernamental }\end{array}$ & $\begin{array}{l}\text { Necessidade de rea- } \\
\text { lizar concurso públi- } \\
\text { co, qualquer que seja } \\
\text { o regime jurídico da } \\
\text { fundação governa- } \\
\text { mental }\end{array}$ \\
\hline $\begin{array}{l}\text { Casos de demis- } \\
\text { são de pessoal }\end{array}$ & $x X X$ & $\begin{array}{l}\text { Prática de falta gra- } \\
\text { ve - acumulação } \\
\text { ilegal de cargos, em- } \\
\text { pregos e funções } \\
\text { públicas - necessi- } \\
\text { dade de redução de } \\
\text { quadro de pessoal, } \\
\text { por excesso de des- } \\
\text { pesa - insuficiência } \\
\text { de desempenho }\end{array}$ & $\begin{array}{l}\text { Prática de falta grave } \\
\text { - acumulação ilegal } \\
\text { de cargos, empregos } \\
\text { e funções públicas } \\
\text { - necessidade de } \\
\text { redução de quadro } \\
\text { de pessoal, por ex- } \\
\text { cesso de despesa } \\
\text { - insuficiência de } \\
\text { desempenho }\end{array}$ \\
\hline $\begin{array}{l}\text { Contrato de ges- } \\
\text { tão e fundação } \\
\text { "pública" }\end{array}$ & $x X X$ & $\begin{array}{l}\text { Para ampliar sua au- } \\
\text { tonomia gerencial, } \\
\text { orçamentária ou fi- } \\
\text { nanceira, a funda- } \\
\text { ção pública poderá } \\
\text { celebrar contrato de } \\
\text { gestão com o Poder } \\
\text { Público }\end{array}$ & $\begin{array}{l}\text { Para ampliar sua au- } \\
\text { tonomia gerencial, or- } \\
\text { çamentária ou finan- } \\
\text { ceira, a fundação pú- } \\
\text { blica poderá celebrar } \\
\text { contrato de gestão } \\
\text { com o Poder Público }\end{array}$ \\
\hline $\begin{array}{l}\text { Contratos de ser- } \\
\text { viço }\end{array}$ & $x x x$ & $\begin{array}{l}\text { “Fundação pública } \\
\text { com personalidade } \\
\text { jurídica de direito pri- } \\
\text { vado" poderá cele- } \\
\text { brar com o Poder } \\
\text { Público contrato de } \\
\text { serviço. }\end{array}$ & $\begin{array}{l}\text { “Fundação pública } \\
\text { com personalidade } \\
\text { jurídica” poderá cele- } \\
\text { brar com o Poder Pú- } \\
\text { blico contrato de ser- } \\
\text { viço. }\end{array}$ \\
\hline $\begin{array}{l}\text { Prestação de ser- } \\
\text { viços à iniciativa } \\
\text { privada }\end{array}$ & $x x x$ & $\begin{array}{l}\text { "Fica vedada à fun- } \\
\text { dação pública que } \\
\text { presta serviços de } \\
\text { acesso universal a } \\
\text { venda desses servi- } \\
\text { ços para a iniciativa } \\
\text { privada." }\end{array}$ & $\begin{array}{l}\text { "Fica vedada, no } \\
\text { caso de fundação } \\
\text { pública que atue na } \\
\text { área de serviços so- } \\
\text { cial público, a venda } \\
\text { de serviços de aces- } \\
\text { so universal para a } \\
\text { iniciativa privada." }\end{array}$ \\
\hline
\end{tabular}




\begin{tabular}{|c|c|c|c|}
\hline & PLP n. 92/2007 & $\begin{array}{c}\text { Primeiro } \\
\text { substitutivo }\end{array}$ & $\begin{array}{l}\text { Segundo } \\
\text { substitutivo }\end{array}$ \\
\hline $\begin{array}{l}\text { Aplicação do art. } \\
198 \text { da CF }\end{array}$ & $X X X$ & $\begin{array}{l}\text { Especialmente os } \\
\text { princípios da regio- } \\
\text { nalização, hierarqui- } \\
\text { zação e descentra- } \\
\text { lização são aplicá- } \\
\text { veis à "fundação } \\
\text { pública com perso- } \\
\text { nalidade jurídica de } \\
\text { direito privado" }\end{array}$ & $\begin{array}{l}\text { Especialmente os } \\
\text { princípios da regiona- } \\
\text { lização, hierarquiza- } \\
\text { ção e descentraliza- } \\
\text { ção são aplicáveis à } \\
\text { "fundação pública } \\
\text { com personalidade } \\
\text { jurídica" }\end{array}$ \\
\hline $\begin{array}{l}\text { Representação e } \\
\text { fundação pública }\end{array}$ & $X X X$ & $\begin{array}{l}\text { "A lei que autorizar } \\
\text { a criação de funda- } \\
\text { ção pública destina- } \\
\text { da à prestação de } \\
\text { serviços de acesso } \\
\text { universal deverá } \\
\text { garantir a represen- } \\
\text { tação de seus tra- } \\
\text { balhadores e dos } \\
\text { usuários nas suas } \\
\text { instâncias de delibe- } \\
\text { ração." }\end{array}$ & $\begin{array}{l}\text { "A lei que autorizar a } \\
\text { criação de fundação } \\
\text { pública destinada à } \\
\text { prestação de servi- } \\
\text { ços de acesso uni- } \\
\text { versal deverá garan- } \\
\text { tir a representação } \\
\text { de seus trabalhado- } \\
\text { res e dos usuários } \\
\text { nas suas instâncias } \\
\text { de deliberação." }\end{array}$ \\
\hline Cessão de pessoal & $X X X$ & \begin{tabular}{|l|} 
A cessão de pesso- \\
al permanente da \\
fundação pública \\
de personalidade \\
jurídica de direito \\
privado para outro \\
órgão ou entidades \\
condiciona-se às \\
situações previs- \\
tas nas leis especí- \\
ficas e exclusiva- \\
mente para exercí- \\
cio de cargo em co- \\
missão ou função \\
de confiança.
\end{tabular} & $\begin{array}{l}\text { A cessão de pessoal } \\
\text { permanente da fun- } \\
\text { dação pública de per- } \\
\text { sonalidade jurídica de } \\
\text { direito privado para } \\
\text { outro órgão ou enti- } \\
\text { dades condiciona-se } \\
\text { às situações previs- } \\
\text { tas nas leis específi- } \\
\text { cas e exclusivamente } \\
\text { para exercício de car- } \\
\text { go em comissão ou } \\
\text { função de confiança. }\end{array}$ \\
\hline $\begin{array}{l}\text { Cláusula revoga- } \\
\text { tória }\end{array}$ & $X X X$ & $X X X$ & $\begin{array}{l}\text { Revogação da Lei } n \text {. } \\
\text { 8.958/1994 (Lei das } \\
\text { Fundações de Apoio) } \\
\text { e da Lei n. 9.790/1999 } \\
\text { (Lei das OSCIP) }\end{array}$ \\
\hline
\end{tabular}




\begin{tabular}{|c|c|c|c|}
\hline & PLP n. 92/2007 & $\begin{array}{c}\text { Primeiro } \\
\text { substitutivo }\end{array}$ & $\begin{array}{l}\text { Segundo } \\
\text { substitutivo }\end{array}$ \\
\hline $\begin{array}{l}\text { Sinônimos empre- } \\
\text { gados ao termo } \\
\text { fundação gover- } \\
\text { namental de direi- } \\
\text { to privado }\end{array}$ & $\begin{array}{l}\text { Fundação sem fins } \\
\text { lucrativos de perso- } \\
\text { nalidade jurídica de } \\
\text { direito privado }\end{array}$ & $\begin{array}{l}\text { Fundação sem fins } \\
\text { lucrativos de perso- } \\
\text { nalidade jurídica de } \\
\text { direito privado - } \\
\text { fundação pública - } \\
\text { fundação pública } \\
\text { com personalidade } \\
\text { jurídica de direito pri- } \\
\text { vado - fundação } \\
\text { pública destinada à } \\
\text { prestação de servi- } \\
\text { ços de acesso uni- } \\
\text { versal }\end{array}$ & $\begin{array}{l}\text { Fundação sem fins } \\
\text { lucrativos de perso- } \\
\text { nalidade jurídica de } \\
\text { direito privado - fun- } \\
\text { dação pública - fun- } \\
\text { dação pública com } \\
\text { personalidade jurídi- } \\
\text { ca de direito privado } \\
\text { - fundação pública } \\
\text { destinada à presta- } \\
\text { ção de serviços de } \\
\text { acesso universal } \\
\text { fundação pública } \\
\text { com personalidade } \\
\text { jurídica - fundação } \\
\text { pública que atue na } \\
\text { área de serviços so- } \\
\text { cial público }\end{array}$ \\
\hline
\end{tabular}

